\title{
Recent glacier variations in Mongolia
}

\author{
KADOTA Tsutomu, ${ }^{1}$ Davaa GOMBO ${ }^{2}$ \\ ${ }^{1}$ Institute of Observational Research for Global Change, 2-15 Natsushima-cho, Yokosuka 237-0061, Japan \\ E-mail: kadota@jamstec.go.jp \\ ${ }^{2}$ Institute of Meteorology and Hydrology, Khudaldaany gudamj-5, Ulaanbaatar-46, Mongolia
}

\begin{abstract}
Glacier monitoring enables us to detect influences of global warming in high mountain regions. To initiate the establishment of a glacier-monitoring network in northern Eurasia, we studied recent glacier variations in Mongolia using topographical maps, aerial photographs and satellite images (Corona and Landsat). Glaciers in Mongolia exist in the Altai mountains which span approximately $1400 \mathrm{~km}$ within Russia, China and Mongolia. Four regions were selected to form the study area: Tavan Bogd region, Turgen massif, Kharkhiraa massif and Tsambagarav massif. During the period from the 1940s to 2000 or from 1968 to 2000 , the glaciers in these regions lost $10.2 \%, 19.3 \%, 28.0 \%$ and $28.8 \%$ of their area respectively. The glaciers in the Tavan Bogd, Kharkhiraa and Turgen regions were found to have been almost stationary since 1987/88, while those in Tsambagarav massif showed no significant change in area since 1963. Shrinkage of the glaciers occurred between 1945/68 and 1987/88 in the former regions and between 1948 and 1963 in the latter. Mongolian glaciers seem to behave differently from other glaciers which have been experiencing steady shrinkage recently.
\end{abstract}

\section{INTRODUCTION}

Environmental changes in high-latitude and -altitude regions due to recent climate warming have been reflected in cryospheric changes such as reduction of the snow-covered area/period. Beniston and Rebetez (1996), for example, reported that warming is greater at higher elevations in the Alps. They considered that the cryosphere, one of the components of the climate system in high mountain regions, was sensitive to climate warming. Global warming could also influence precipitation amount/distribution and this would affect the water cycle along with the runoff process due to possible shrinkage of permafrost. Monitoring of the fragile cryosphere enables early detection of changes in the region. Glaciers, one of the notable components of the cryosphere, are a potential indicator of changing climate, especially in high and remote mountain regions where no permanent climate station exists. The critical link between glaciers and climate is glacier mass balance. Such glaciological data, however, have come mostly from Europe and North America, while data from northern Eurasia, where major climatic change could occur due to global warming, have been few. To initiate the establishment of a glaciermonitoring network in northern Eurasia, we studied recent variations of Mongolian glaciers using the materials presently available.

\section{STUDY AREA}

Glaciers in Mongolia exist in the Altai mountains, which span approximately $1400 \mathrm{~km}$ within Russia, China and Mongolia (Fig. 1). Four regions (A-D in Fig. 1) were selected to form the study area. Glaciers in the Tavan Bogd region are of the valley type, in Turgen and Kharkhiraa massif are a mixture of two types (valley type and flat-top type), whereas in Tsambagarav massif flat-top-type glaciers are dominant. The mean highest/lowest glacier elevations obtained from the topographical maps listed in section 3.1 are 3598/2884, 3796/3159, 3647/3179 and 4013/3144 ma.s.l. in Tavan Bogd, Turgen, Kharkhiraa and Tsambagarav, respectively.
The highest point, on Khuiten mountain, is $4374 \mathrm{~m}$ a.s.l. and the longest/largest glacier is Potanin glacier which is about $11 \mathrm{~km}$ long and $43 \mathrm{~km}^{2}$ in area. The climate is continental and semi-arid. Figure 2 shows the mean (1961-90) monthly air temperature and precipitation at Khovd. The mean annual air temperature and precipitation are $-3.5^{\circ} \mathrm{C}$ and $138 \mathrm{~mm}$. About $70 \%$ of annual precipitation occurs in the summer (June-August). The borehole temperature below $5 \mathrm{~m}$ was about $-18^{\circ} \mathrm{C}$, and the annual mean accumulation rate was $250 \mathrm{~mm}$ w.e., these values being derived from $10 \mathrm{~m}$ deep ice-core drilling at the summit $(4000 \mathrm{~m}$ a.s.l) of Tsast Uul ice cap (located to the west of Tsambagarav) in June 1991 (Schotterer and others, 1997).

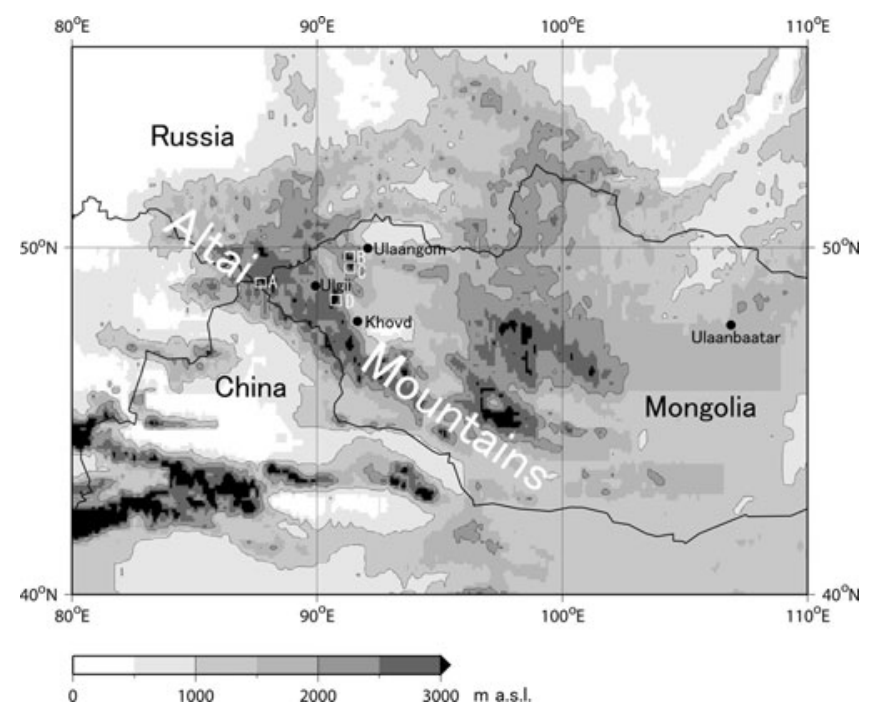

Fig. 1. Study areas in the Altai mountains in Mongolia: A: Tavan Bogd region; B: Turgen massif; C: Kharkhiraa massif; D: Tsambagarav massif. Three nearby meteorological stations, Ulgii (1715 m a.s.l.), Ulaangom (939 m a.s.l.) and Khovd (1405 m a.s.l.), are also shown. 


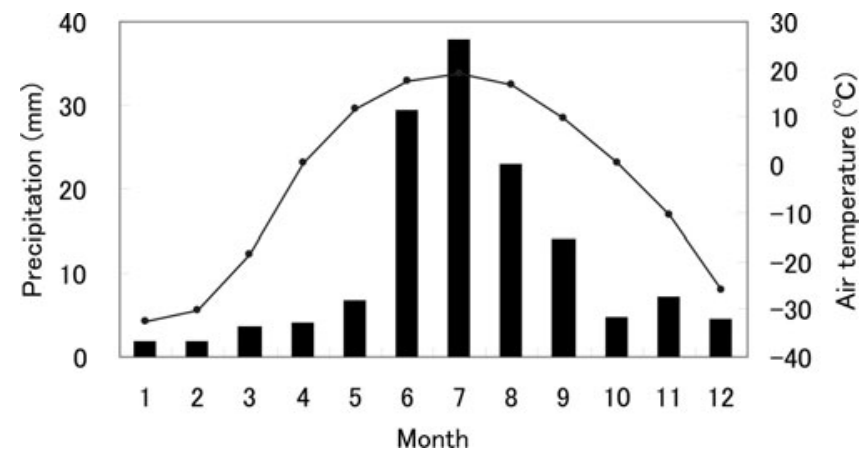

Fig. 2. Mean (1961-90) monthly air temperature (curve: right axis) and precipitation (bars: left axis) at Khovd. About $70 \%$ of total precipitation occurs in summer (June-August).

\section{DATA}

Four kinds of data were used in this study as follows:

\subsection{Topographical maps (scale $1: 100000$ ) published in 1970 and 1971}

Tavan Bogd region: M45-104 (based on air photographs taken in 1945)

Turgen massif: M46-75, M46-87 and M46-88 (based on air photographs taken in 1968)

Kharkhiraa massif: M46-87 (based on air photographs taken in 1968)

Tsambagarav massif: M46-110, M46-122 (based on air photographs taken in 1948)

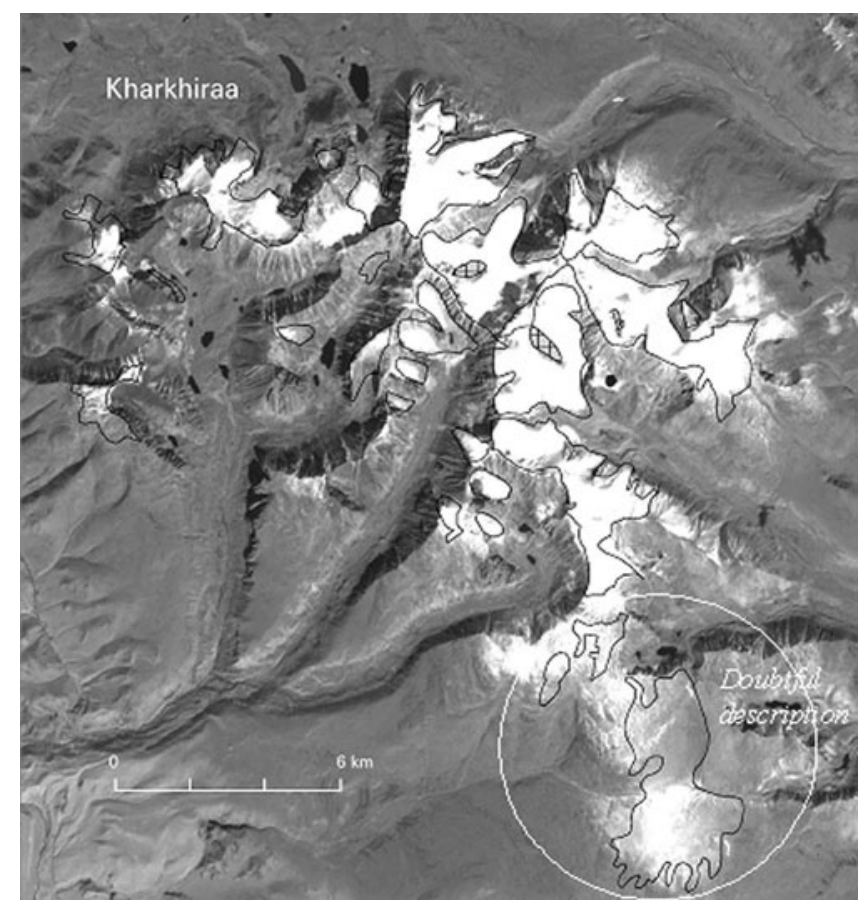

Fig. 3. An overlay view of the image of Kharkhiraa massif. The solid lines denote glacier area drawn in the topographical map. The image is Landsat 7 ETM+ band 8, path 145, row 25, taken on 10 September 2000. The southernmost glacier area described in the map, indicated by an arrow, could not be identified and was discounted from this study.

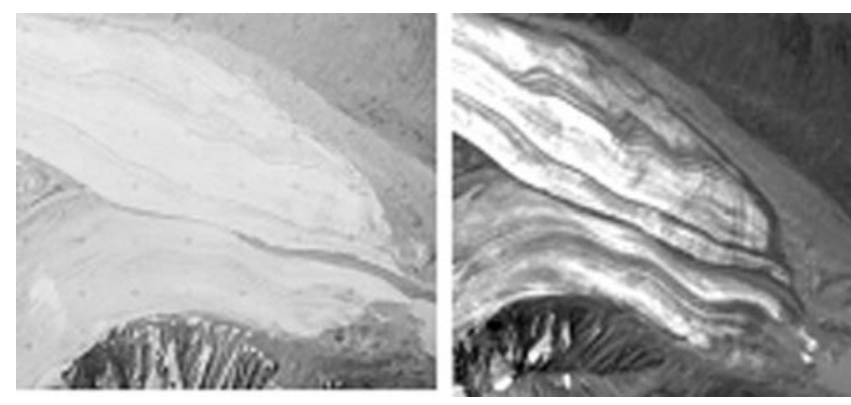

Fig. 4. The tongue of Potanin glacier in 1988 (left) and in 2000 (right). There is no obvious change in its shape or position.

\subsection{Landsat 7 Enhanced Thematic Mapper Plus (ETM+) band 8}

Tavan Bogd region: path 143, row 26, 6 August 2000

Turgen/Kharkhiraa massifs: path 142, row 25, 10 September 2000

Tsambagarav massif: path 142, row 26, 10 September 2000

\subsection{Corona photos (black-and-white positives)}

Tavan Bogd region: 22 June 1962

Tsambagarav massif: 26 August 1963 and 11 August 1968

\subsection{Aerial photographs (scale $1: 43000$ to $1: 45000$ )}

Tavan Bogd region: 4 and 7 September 1988

Turgen massif: 21 July 1988

Kharkhiraa massif: 2 July 1988

Tsambagarav massif: 20 July and 19 September 1987

\section{METHODS}

The quality of materials presently available led to the use of the following two methods. Method 1 enabled us to evaluate changes in glaciers quantitatively, while method 2 gave us only qualitative changes.

\subsection{Method 1}

1. Geometrical rectification of the Landsat images with the maps

2. Comparison between the maps and the Landsat images

The images were geometrically rectified using about 20 points identified in the corresponding maps, evenly distributed around the massif. Root-mean-square errors were less than one pixel $(<15 \mathrm{~m})$. The areas of the glaciers in the images were then measured and compared with those in the maps. Figure 3 shows an overlay view of the image of Kharkhiraa massif as an example. 

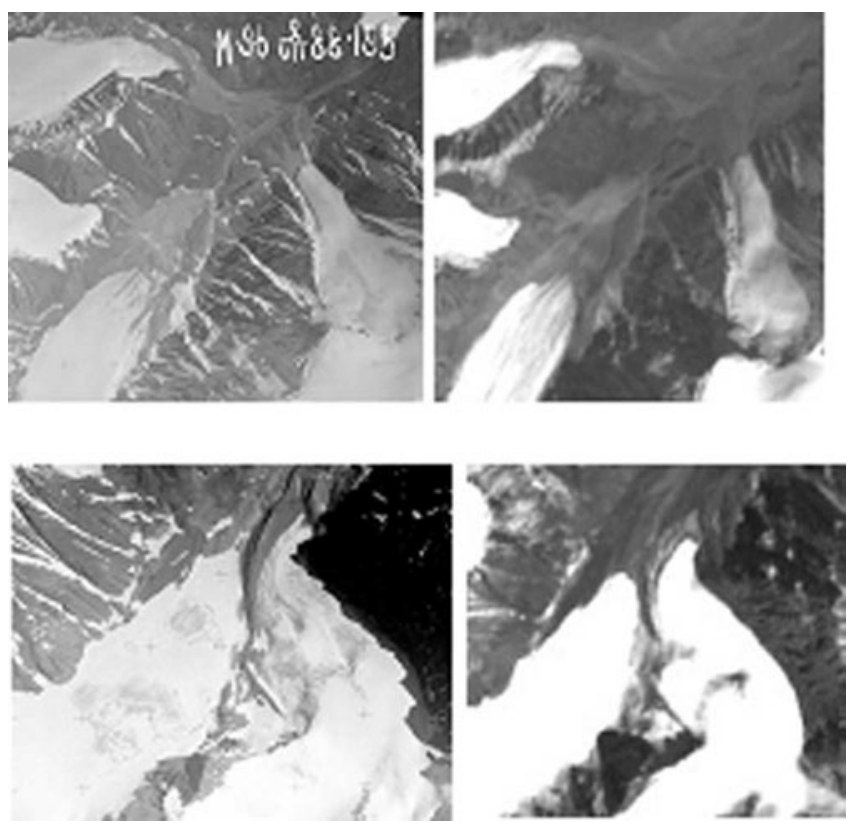

Fig. 5. Tongues of glaciers in Turgen (top) and Kharkhiraa (bottom) massifs in 1988 (left) and in 2000 (right). No obvious change is identified between the two years.

\subsection{Method 2}

1. Comparison between Landsat images and Corona photos

2. Comparison between Landsat images and aerial photos

3. Comparison between Corona photos and aerial photos

These procedures were carried out visually, because we could not rectify aerial photos and Corona photos with the maps and/or Landsat images. Figures 4-6 show examples of pairs for comparison.

\section{RESULTS}

The changes in area obtained by method 1 are compiled in Table 1. The glaciers in the study area lost $10-30 \%$ of their area during the period from the 1940s to 2000 or from 1968 to 2000 .

As shown in Figures 4-6, the glaciers in Tavan Bogd, Kharkhiraa and Turgen regions have been almost stationary since $1987 / 88$. This means that retreat of the glaciers

Table 1. Changes of glacier area in four regions, derived by comparing maps with satellite images. The maps of Tavan Bogd and Tsambagarav are considered to represent states of glaciers in the 1940s, and those of Turgen and Kharkhiraa represent states of glaciers in 1968 (see text). Note that part of the glacier area on the map of Kharkhiraa was discounted

\begin{tabular}{lcc}
\hline Region & Area as of $1970 / 71$ map & Area lost by 2000 \\
& $\mathrm{~km}^{2}$ & $\mathrm{~km}^{2}(\%)$ \\
\hline Tavan Bogd & 88.88 & $9.11(10.2)$ \\
Turgen & 43.02 & $8.28(19.3)$ \\
Kharkhiraa & 50.13 & $14.05(28.0)$ \\
Tsambagarav & 105.09 & $30.29(28.8)$ \\
\hline
\end{tabular}

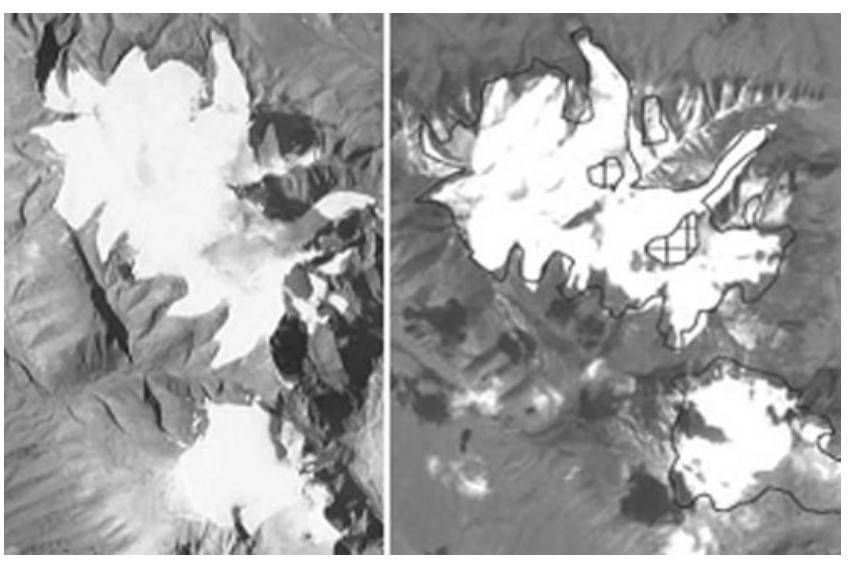

Fig. 6. Glaciers in Tsambagarav massif in 1963 (left) and in 2000 (right). There is no obvious change in shapes of glaciers between the two years.

occurred between 1945 and 1987/88 in Tavan Bogd region and between 1968 and 1987/88 in Kharkhiraa and Turgen regions. The glaciers in Tsambagarav massif showed no significant change in area since 1963. This suggests the reduction in glacier area occurred mainly between 1948 and 1963.

The results obtained by the two methods are summarized in Figure 7.

\section{DISCUSSION}

Of the four regions, Tsambagarav showed the largest loss of glacier area in the shortest period. As mentioned in section 2, flat-top-type glaciers predominate in this region. Narozhniy and Nikitin (2003) found a similar tendency in glacier area reduction in the Russian Altai. They showed that flat-top-type glaciers lost $16.1 \%$ of their area on average (range $8-30 \%$ ), whereas valley glaciers lost $4 \%$ of their area (range 2.5-8\%) during 1954-98. Flat-top-type glaciers are more sensitive to equilibrium-line-altitude (ELA) change than valley-type glaciers, because even a small shift in ELA affects a large area of flat-top-type glaciers. This implies that climatic warming, especially during the summer, raises the ELA, causing this glacier shrinkage. Figure 8 shows anomalies of summer (June-August) air temperatures and annual precipitation at the three meteorological stations shown in Figure 1. At Ulgii and Khovd it was relatively warm

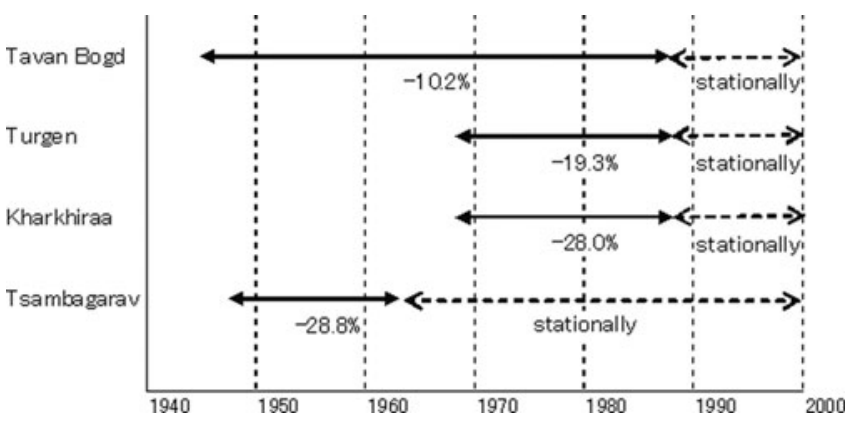

Fig. 7. Glacier shrinking periods/magnitudes for each region obtained in this study. 
Ulgii (1715 m)

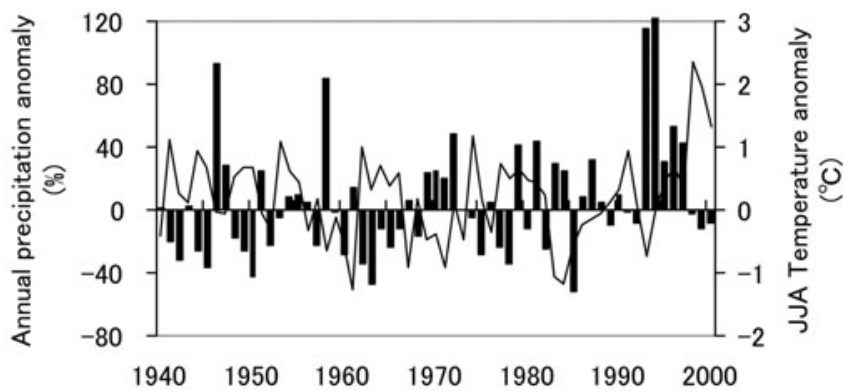

Ulaangom (939 m)

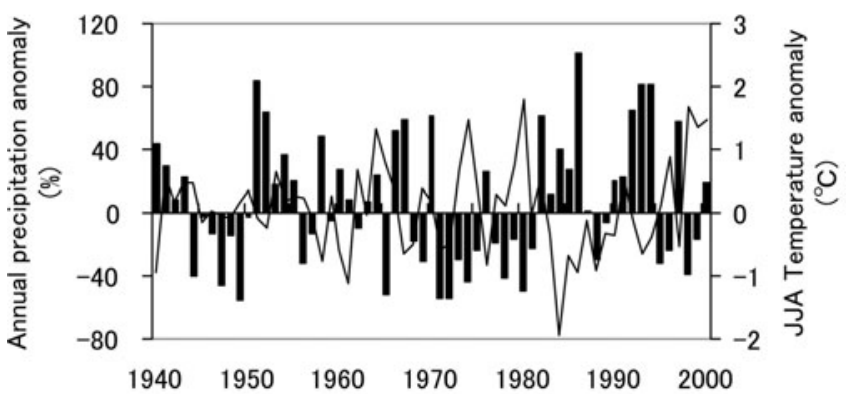

Khovd (1405 m)

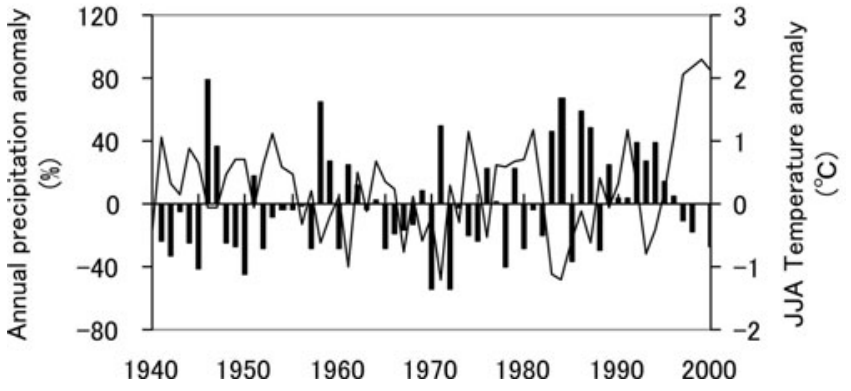

Fig. 8. Climatological data at the meteorological stations Ulgii, Ulaangom and Khovd, 1940-2000. Mean summer (June-August (JJA)) air temperature (curves) and annual precipitation (bars) are shown, as anomalies from 1961-90 mean. Elevations of the stations are shown in parentheses.

and dry from 1940 to the mid-1950s, when the glaciers in this region shrank. Warm periods occurred in the mid1960s, 1970s and late 1990s, but no significant changes were observed in the glaciers. They may have lost enough area in the period from 1940 to the mid-1950s that they held onto their shrunken area in the following warm periods, i.e. they reached a state of near-equilibrium with the first warm and dry climate. However, there remains the possibility that thinning of glacier ice could have occurred. Glaciers in the Turgen/Kharkhiraa regions lost area during the period 1968$1987 / 88$. Lehmkuhl (1998) reported that glaciers in Turgen retreated 200-500 m between 1948 and 1991. At the nearby meteorological station Ulaangom, conditions were warm and dry in the 1970s and then cool and wet till the mid1990s (Fig. 8).
The shrinkage of Mongolian glaciers between the 1940s and the late 1980s in this study suggests that climatic warming occurred in the glaciated regions of Mongolia. In the Russian Altai, Henderson and others (2006) found a summer (June-August) air-temperature warming of $1.6^{\circ} \mathrm{C}$ over the last century by analyzing the melt percentage of the ice cores recovered at Belukha col $\left(49^{\circ} 48^{\prime} 26.3^{\prime \prime} \mathrm{N}\right.$, $86^{\circ} 34^{\prime} 42.8^{\prime \prime} \mathrm{E} ; 4062 \mathrm{~m}$ a.s.l.). They identified a transition towards a warmer trend at 1940-50. On the other hand, Sofiyskiy glacier, Russian Altai, has been retreating steadily since the beginning of the 20th century. Average retreat rates are 18.3, 17.3 and $8.6 \mathrm{~m} \mathrm{a}^{-1}$ during the periods $1898-2000$, 1939-63 and 1963-2000 respectively (after Pattyn and others, 2003). However over the last decade, at least, Mongolian glaciers showed no significant change. Mongolian glaciers seem to behave differently from other glaciers which have been experiencing steady shrinkage throughout the period.

\section{CONCLUDING REMARKS}

The glacier variations described in this study are limited to shapes and area. It may be that downwasting occurred, even though no change in glacier area was found. Information on surface elevation changes is needed; the climatological data available are limited to low elevations. Furthermore, massbalance studies are required that will link glaciers to climate. In order to understand the relation between glacier change and climate, we commenced in situ observations (e.g. of mass balance, flow and depth) of Mongolian glaciers in September 2003. First results will be published elsewhere in the near future.

\section{ACKNOWLEDGEMENTS}

We appreciate comments and suggestions from R. Armstrong and an anonymous reviewer, which improved the manuscript.

\section{REFERENCES}

Beniston, M. and M. Rebetez. 1996. Regional behaviour of minimum temperatures in Switzerland for the period 19791993. Theor. Appl. Climatol., 55(3/4), 231-243.

Henderson, K., A. Laube, H.W. Gäggeler, S. Olivier, T. Papina and M. Schwikowski. 2006. Temporal variations of accumulation and temperature during the past two centuries from Belukha ice core, Siberian Altai. J. Geophys. Res., 111(D3), D03104. (10.1029/2005JD005819.)

Lehmkuhl, F. 1998. Quaternary glaciation in central and western Mongolia. Quat. Proc., 6, 153-167.

Narozhniy, Yu.K. and S.A. Nikitin. 2003. Recent glaciation of Altai at the beginning of the 21st century. Mater. Glyatsiol. Issled./Data Glaciol. Stud. 95, 93-101. (In Russian with English summary.)

Pattyn, F. and 6 others. 2003. Ice dynamics and basal properties of Sofiyskiy glacier, Altai mountains, Russia, based on DGPS and radio-echo sounding surveys. Ann. Glaciol., 37, 286-292.

Schotterer, U., K. Fröhlich, H.W. Gäggeler, S. Sandjordj and W. Stichler. 1997. Isotope records from Mongolian and Alpine ice cores as climate indicators. Climatic Change, 36(3-4), 519-530. 